\title{
Biomarkers in EndoVascular Aneurysm Repair (EVAR) and Abdominal Aortic Aneurysm: Pathophysiology and Clinical Implications
}

\author{
Francesco Stilo ${ }^{1}$, Vincenzo Catanese ${ }^{1, *}$, Antonio Nenna ${ }^{2}$ D, Nunzio Montelione ${ }^{2}$, Francesco Alberto Codispoti ${ }^{2}$, \\ Emanuele Verghi ${ }^{2}$, Teresa Gabellini ${ }^{3}$, Mohamad Jawabra ${ }^{2}$, Massimo Chello ${ }^{2}$ (D) and Francesco Spinelli ${ }^{2}$ \\ 1 Department of Vascular Surgery, Campus Bio-Medico University, 00128 Rome, Italy; f.stilo@unicampus.it \\ 2 Department of Cardiovascular Surgery, Campus Bio-Medico University, 00128 Rome, Italy; \\ a.nenna@unicampus.it (A.N.); n.montelione@unicampus.it (N.M.); f.codispoti@unicampus.it (F.A.C.); \\ e.verghi@unicampus.it (E.V.); mohamad.jawabra@unicampus.it (M.J.); M.Chello@unicampus.it (M.C.); \\ f.spinelli@unicampus.it (F.S.) \\ 3 Residency Program of Vascular and Endovascular Surgery, University of Ferrara, 44121 Ferrara, Italy; \\ teresa.gabellini91@gmail.com \\ * Correspondence: dr.vincenzocatanese@gmail.com or v.catanese@unicampus.it
}

check for updates

Citation: Stilo, F.; Catanese, V.; Nenna, A.; Montelione, N.; Codispoti, F.A.; Verghi, E.; Gabellini, T.; Jawabra, M.; Chello, M.; Spinelli, F. Biomarkers in EndoVascular Aneurysm Repair (EVAR) and Abdominal Aortic Aneurysm: Pathophysiology and Clinical Implications. Diagnostics 2022, 12, 183. https://doi.org/ 10.3390/diagnostics12010183 Academic Editor: Paolo Zamboni

Received: 12 December 2021 Accepted: 11 January 2022

Published: 13 January 2022

Publisher's Note: MDPI stays neutral with regard to jurisdictional claims in published maps and institutional affiliations.

Copyright: (C) 2022 by the authors. Licensee MDPI, Basel, Switzerland. This article is an open access article distributed under the terms and conditions of the Creative Commons Attribution (CC BY) license (https:// creativecommons.org/licenses/by/ $4.0 /)$.

\begin{abstract}
Circulating biomarkers have been recently investigated among patients undergoing endovascular aortic aneurysm repair (EVAR) for abdominal aortic aneurysm (AAA). Considering the plethora of small descriptive studies reporting potential associations between biomarkers and clinical outcomes, this review aims to summarize the current literature considering both the treated disease (post EVAR) and the untreated disease (AAA before EVAR). All studies describing outcomes of tissue biomarkers in patients undergoing EVAR and in patients with AAA were included, and references were checked for additional sources. In the EVAR scenario, circulating interleukin-6 (IL-6) is a marker of inflammatory reaction which might predict postoperative morbidity; cystatin $\mathrm{C}$ is a promising early marker of post-procedural acute kidney injury; plasma matrix metalloproteinase-9 (MMP-9) concentration after 3 months from EVAR might help in detecting post-procedural endoleak. This review also summarizes the current gaps in knowledge and future direction of this field of research. Among markers used in patients with AAA, galectin and granzyme appear to be promising and should be carefully investigated even in the EVAR setting. Larger prospective trials are required to establish and evaluate prognostic models with highest values with these markers.
\end{abstract}

Keywords: abdominal aortic aneurysm; endovascular aortic aneurysm repair; biomarkers; endoleak; matrix metalloproteinases; interleukin-6; cystatin C

\section{Introduction}

Abdominal aortic aneurysm (AAA) is a multifactorial disease and a potentially lifethreatening condition. Pharmacological approaches to slow aneurysm progression and limit the near-fatal risk of acute ruptures are currently under investigation to reduce the negative impact on the healthcare system [1]. Endovascular aortic aneurysm repair (EVAR) has now become the standard of care which has been shown to reduce morbidity and mortality [2]. However, short-term and long-term complications still hamper procedural success, and the most common complication is the residual perfusion of the aneurysmal sac (i.e., endoleak). Considering their frequency, patients undergo long-term surveillance screening with computed tomographic angiography or vascular ultrasound, which are limited by contrast administration or poor accuracy, respectively. Post-procedural complications and their assessment might impact the cost-effectiveness of EVAR.

Therefore, the study of circulating biomarkers has been progressively introduced in the medical literature and in the near future, these biomarkers might help in identifying 
conditions prone to develop complications, for both post-EVAR patients and patients with aortic aneurysm in follow up. This review will discuss the current biomarkers in the setting of AAA, with particular emphasis on patients undergoing EVAR.

\section{Materials and Methods}

An electronic database search through PubMed and Scopus was performed in October 2021. All studies describing outcomes of tissue biomarkers in patients undergoing EVAR were included, and references were checked for additional sources. Case reports, opinions, and editorials were excluded. Pre-clinical studies (non-human studies) were considered only for the last paragraph of the results.

\section{Results}

Pre-clinical evidence was considered only if directly connected with human results, and potential implications for future research are discussed separately. In the presentation of results, the treated disease (i.e., EVAR) and the untreated disease (i.e., AAA) will be separated.

\section{Biomarkers and Compounds in EVAR (Treated Disease)}

After AAA repair, the hormonal and metabolic stress-related inflammatory cascade, clinically referred to as "post-implantation syndrome", is rapidly activated [3] by surgical trauma, ischemia-reperfusion injury and local cellular interactions [3]. Although endovascular repair reduces tissue manipulation compared with open surgery, intra-luminal manipulation of the thrombus using catheters is sufficient to initiate and sustain this strong systemic inflammatory response. Inflammatory cytokines and their regulatory activities have been extensively investigated in recent years, and a systematic review [3] concluded that IL-6 and IL-8 were particularly involved in the post-implantation syndrome and their role is greater in open surgery. IL-1b, IL-10, and TNF-a are other final common pathways of the post-implantation syndrome with no differences between open and EVAR techniques [3].

After EVAR, the most common and serious complication is endoleak, which is generally diagnosed with computed tomography during surveillance follow up or in case of symptoms. Assessment of markers released from the aneurysm wall into the bloodstream might potentially be an alternative for early endoleak detection [1]. Among those biomarkers, matrix metalloproteinases (MMPs) are soluble enzymes with lytic activity produced by macrophages and vascular smooth muscle cells. In particular, MMP-9 has been implicated in aneurysm growth through structural changes in the aortic wall and ECM remodeling, and its soluble release in the bloodstream has been advocated as a marker for endoleak, as the continuous perfusion of the aneurysm sac promotes MMP-9 release in the bloodstream [1]. A meta-analysis by Ng et al. [1] concluded that patients with endoleak have higher 3-month values of plasma MMP-9 levels compared to patients without endoleak (SMD 1.42, 95\%CI 0.48-2.36, $p<0.003$ ) [1], echoing previous studies [4].

Another feared complication of EVAR is perioperative renal dysfunction, related to contrast medium or reduced flow to renal arteries [2]. Anuria is a tardive event in acute kidney disease and urine output cannot be reliably considered the unique indicator. A recent systematic review [2] concluded that neutrophil gelatinase associated lipocalin (NGAL), cystatin C, and liver-type fatty acid binding protein (FABP-L) were the most promising for assessing postoperative renal failure after EVAR [2]. Considering "classic" biomarkers, serum creatinine $>1.5 \mathrm{mg} / \mathrm{dL}$ remains a strong predictor of increased 30-day mortality (RR 3.0, 95\% CI 2.3-4.1, $p<0.001$ ) [5].

Another aspect recently reviewed in literature is the coagulation cascade. As aneurysm leads to increased thrombin generation and fibrin turnover, EVAR could produce similar results. A recent review [6] concluded that EVAR increased thrombin activation and fibrinolysis up to one year after procedure, suggesting that this period might be associated with increased risk of cardiovascular events and confirming previous findings [7]. Moreover, 
elevated levels of fibrinogen degradation products (FDP) were correlated with endoleak. However, the impact of these changes in the coagulation and fibrinolysis on the outcomes of EVAR should be still investigated.

Studies investigating biomarkers in EVAR disease are summarized in Table 1. Due to their genetic regulatory function and their high stability in biological fluids, plasmatic miRNAs have been highlighted as being optimal candidates as non-invasive biomarkers. For instance, a recent study found that elevated miRNA-1281 levels might identify patients with follow-up complications [8]. Most of the current literature is based on predicting post-operative renal disease, with Cystatin $C$ being the recognized early marker of renal failure [9] (Figure 1).

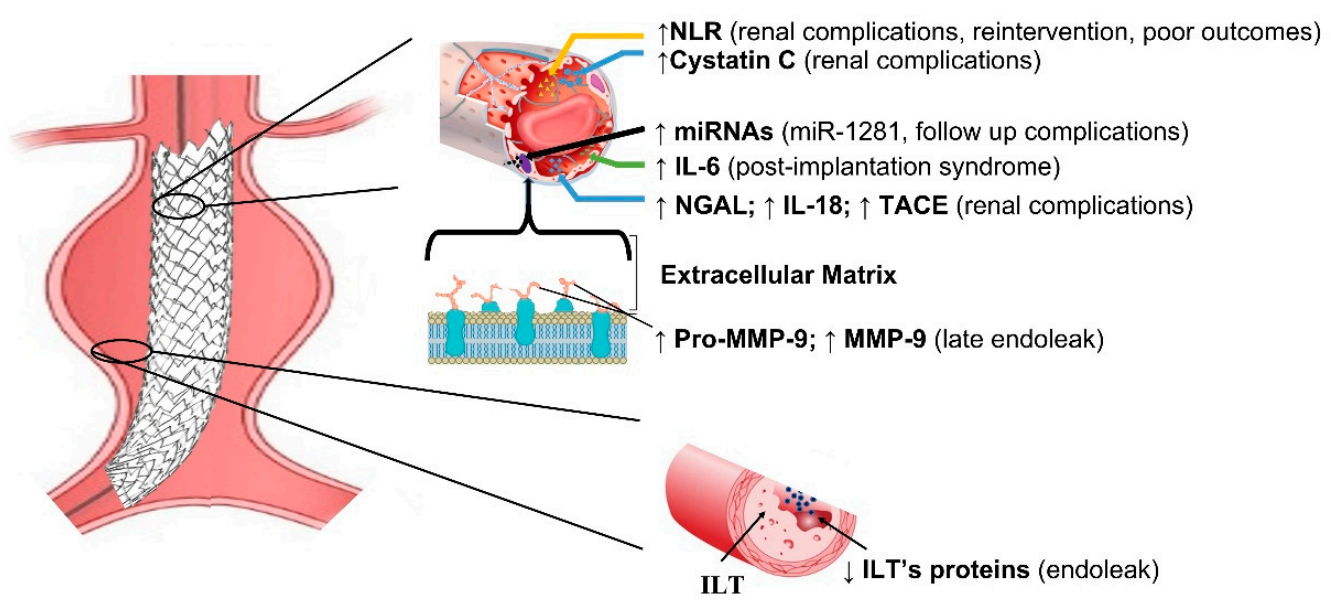

Figure 1. Schematic representation of main biomarkers in EVAR. NLR = Neutrophil-to-Lymphocyte ratio; IL-6 = interleukin 6; IL-18 = interleukin 18; NGAL = Neutrophil gelatin-associated lipocalin; TACE $=$ tumor necrosis factor $-\alpha$ converting enzyme; ILT $=$ intraluminal thrombus; ILT's proteins = intraluminal thrombus proteins; MMP-9 = matrix metalloproteinase and tissue inhibitors; miRNAs = micro RNA.

\section{Biomarkers and Compounds in Abdominal Aortic Aneurysms (Untreated Disease)}

The thorough understanding of AAA pathophysiology has been clarified by proteomic analysis; specific proteins associated with AAA might be released from vascular tissue, intraluminal thrombus, tissue secretome, blood, and cells $[10,11]$. Proteomic analysis found biomarkers of complications, proteins related to pathogenic mechanisms, and potential therapeutic targets for AAA to be confirmed by tailored studies.

Differently from EVAR, in the setting of AAA there are known predictors of complications which have been investigated through the years such as serum elastin peptides (SEP) and plasmin-antiplasmin (PAP) complexes, MMP-9, IL-6, C-reactive protein (CRP), antitrypsin and IFN-gamma for AAA size, expansion rate or rupture [12-16]. Circulating, biomechanical, and genetic markers for AAA growth and rupture were reviewed in recent years [17-22].

Current biomarkers in aortic aneurysm are summarized in Table 2. Genetic features of AAA have been extensively investigated in recent years using microarray, and genes involved in apoptosis, proteolysis, and humoral immune response yielded the most promising results. ALOX5, PTGIS, and CX3CL1 genes are potentially related with diagnosis of AAA $[23,24]$. Similarly, miRNA profiling produced under-expressed and overexpressed sequences suggesting the role in regulatory mechanisms [25-27]. Tissue factors related with inflammatory infiltrates and matrix degradation, such as pentraxin [28], galectin [29], calprotectin [30,31], kallikrein [32], and granzyme [33], correlate with the presence of AAA and might help in identifying patients at risk of AAA rupture (Figure 2). 


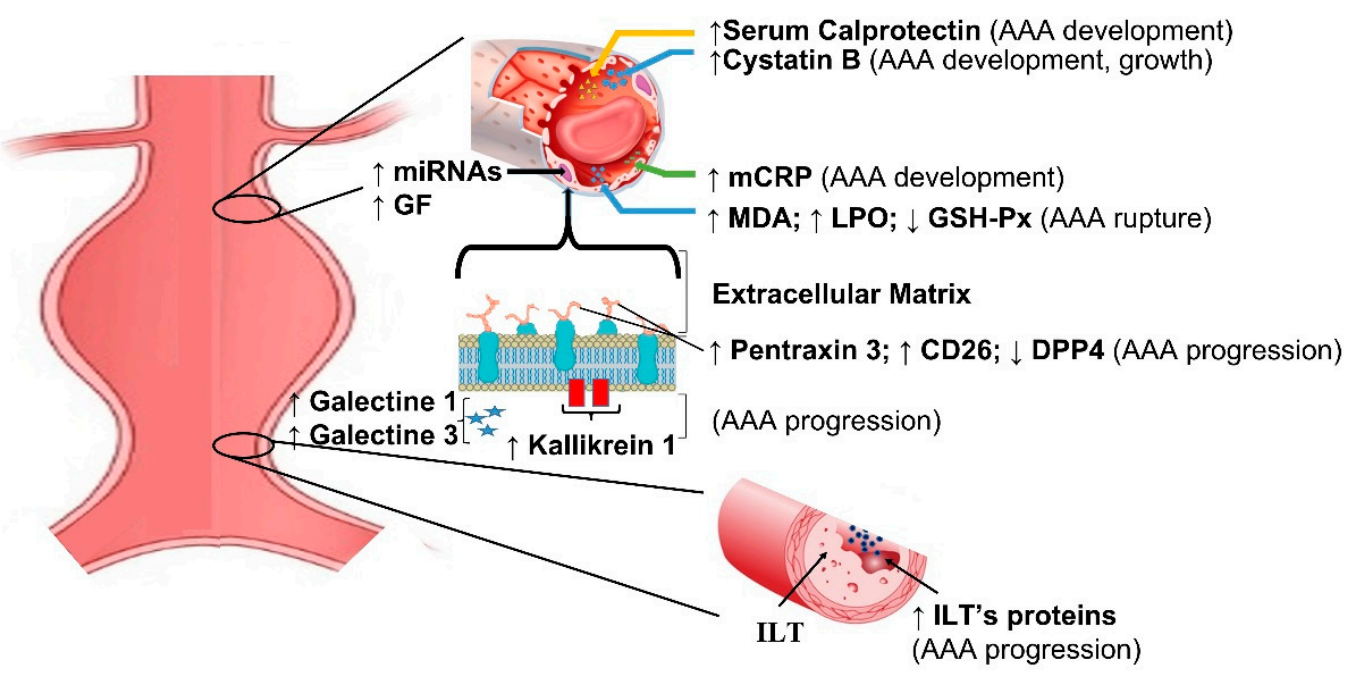

Figure 2. Schematic representation of main biomarkers in abdominal aortic aneurysms. $\mathrm{mCRP}=$ monomeric form of $\mathrm{C}$-reactive protein; $\mathrm{MDA}=$ malondialdehyde; $\mathrm{LPO}=$ lipid hydroperoxide; GSH-Px = glutathione peroxidase; DPP4 = dipeptidyl peptidase-4; ILT = intraluminal thrombus; ILT's proteins = intraluminal thrombus proteins; miRNAs = micro RNA; GF = genetic factors.

Some recent reviews summarized the impact of miRNA and long non coding RNA (lncRNA) in cellular processed involved in abdominal aortic aneurysm [34-39]. Although some lncRNAs have been described as dysregulated in models or human tissue of AAA, comparatively few studies exist to date that have established their functional roles in pathologic disease.

\section{The Common Background between EVAR and Untreated AAA: Extracellular Matrix}

The pathogenesis of abdominal aortic aneurysm (AAA) is characterized by medial degeneration, manifesting with elastic fiber fragmentation, collagen fiber disorganization, and proteoglycan accumulation, as well as vascular smooth muscle cells (VSMC) loss [40]. The destruction of aortic connective tissue in AAA is led by a severe inflammatory reaction causing excessive degradation of the aortic extracellular matrix (ECM), which plays a pivotal role in AAA pathogenesis [40].

Vascular smooth muscle cells (VSMCs) play an important role in aorta homeostasis by secreting metalloproteinases (MMPs) and their inhibitors (TIMPs). As previously reported, MMPs, in particular MMP-9, have been implicated in aneurysm growth through structural changes in the aortic wall and ECM remodeling [40]. Previous studies have reported that excessive MMP secretion in the aortic wall leads to abnormal ECM degradation [41,42]. This important degradation of the ECM induces the release of cytokines which are involved in the regulation of ECM homeostasis [43]. All of these pathological events lead to weakening of the aortic wall, overexposing it to the biomechanical forces of pulsatile blood flow and blood pressure. Recent studies have reported a link between genetic defects in several collagen-encoding genes (i.e., COL1A1, COL1A2, COL3A1, COL5A1, and COL4A1/A2) and the development of AAA, thoracic abdominal aneurysm (TAA), and aortic dissection $[44,45]$. Moreover, mutation in COL3A1 can be found in more than $95 \%$ of patients with Ehlers-Danlos syndrome (EDS) with aortic complications [46]. An important role in the pathogenesis of AAA is represented by the degradation of elastin. The template for elastin is provided by fibrillin, which is a large extracellular glycoprotein that assembles to form microfibrils that are key components of most of the ECM. Fibrillin-1 (FBN1) and fibrillin-2 (FBN2) are the main structural components of the microfibril scaffold [45].

Pathologically increased of TGF- $\$$ signaling was first implicated in the pathogenesis of TAA in the context of Marfan syndrome [47]. Furthermore, the role of dysregulated TGF- $B$ signaling in the pathogenesis of syndromic TAA is explained by the identification 
of loss-of-function mutations in TGF- $§$ receptors (TGFßR1 and TGFßR2), ligands (TGFß2 and TGFB3), and downstream effectors (SMAD2 and SMAD3) in patients with Loeys-Dietz syndrome $[47,48]$. Recently, new studies have proposed proteomics methods for a more systematic analysis of extracellular proteins $[48,49]$. One of the newest ECM proteomics approaches provides an activity-based proteomics method to relate the activity of specific proteases to ECM degradation components and to identify novel protease targets [49]. Furthermore, the latest glycoproteomics technologies allow an analysis of the glycosylation changes of ECM proteins in the arterial wall [50]. A recent finding, with a study on glycoproteomics, revealed an increase in MFAP4 in patients with MFS compared to control aneurysmatic patients [50]. Furthermore, TGF- $\beta$ was observed to induce MFAP4 expression in both human and mouse VSMCs, and MFAP4 was upregulated in aortic specimens from patients with a predisposition to AAA [50].

\section{Evidence from Pre-Clinical Studies}

Potential new biomarkers from recent pre-clinical studies are summarized in Table 3. Epigenetic mediators such as citrullinated histone $\mathrm{H} 3$ appear to be a promising therapeutic target for AAA [51]. Similarly, miRNA silencing and the PTEN pathway will have a role in modulating AAA progression and changing cell viability [52-54].

Table 1. Potential new biomarkers from recent pre-clinical studies.

\begin{tabular}{|c|c|c|c|}
\hline Biomarker/Compound & Study Type & Biological Effect and In-Vivo Implication & Reference \\
\hline $\begin{array}{l}\text { Neutrophil extracellular traps (NETs), citrullinated } \\
\text { histone H3 }\end{array}$ & mice & $\begin{array}{l}\text { citH3 represents a promising AAA biomarker and } \\
\text { potential therapeutic target. Inhibitor of citH3 block } \\
\text { the AAA progression in mice. }\end{array}$ & [51] \\
\hline $\operatorname{miR}-188-5 p$ & mice & $\begin{array}{l}\text { Expression of miR-188-5p is increased in experimental } \\
\text { AAAs. Treatment with miR-188-5p inhibition limits } \\
\text { experimental AAA progression, with histologic } \\
\text { evidence of reduced neovessels and attenuated mural } \\
\text { leukocyte infiltration. }\end{array}$ & [54] \\
\hline myeloid related protein 8/14 (MRP8/14) & rat & $\begin{array}{l}\text { MRPs especially for MRP8/14 increased the levels of } \\
\text { MMP-2 and MMP-9 in rat models. } \\
\text { RP8/14 was associated with AAA presence } \\
\text { and progression }\end{array}$ & [105] \\
\hline $\begin{array}{l}\mathrm{C} 1 \mathrm{q} / \text { tumor necrosis factor }(\mathrm{TNF}) \text {-related } \\
\text { protein-13 (CTRP13) }\end{array}$ & mice & $\begin{array}{l}\text { CTRP13 was shown to effectively reduce the incidence } \\
\text { and severity of AAA in conjunction with reduced } \\
\text { aortic macrophage infiltration, expression of } \\
\text { proinflammatory cytokines (interleukin-6 [IL-6], } \\
\text { TNF- } \alpha \text {, and monocyte chemoattractant protein } 1 \\
\text { [MCP-1]), and vascular smooth muscle cell (SMC) } \\
\text { apoptosis. Mechanistically, nicotinamide } \\
\text { phosphoribosyl-transferase } 1 \text { (NAMPT1) was } \\
\text { identified as a new target of CTRP13. NAMPT1 } \\
\text { knockdown blocked the beneficial effects of CTRP13 } \\
\text { on vascular inflammation and SMC apoptosis. } \\
\text { CTRP13 management may be an effective treatment for } \\
\text { preventing AAA formation }\end{array}$ & [106] \\
\hline Differentially expressed genes (DEGs) of proteases & mice & $\begin{array}{l}43 \text { DEGs were correlated with the expression of the } \\
\text { protease profile, and most were clustered in immune } \\
\text { response module. Mmp16 and Mmp17 were } \\
\text { significantly downregulated in AAA mice, while Ctsa, } \\
\text { Ctsc, and Ctsw were upregulated. that these ectopic } \\
\text { genes are potentially crucial to AAA formation and } \\
\text { may act as biomarkers for the diagnosis of AAA. }\end{array}$ & [107] \\
\hline
\end{tabular}


Table 1. Cont.

\begin{tabular}{lll}
\hline Biomarker/Compound & Study Type & Biological Effect and In-Vivo Implication \\
\hline & & $\begin{array}{l}\text { Increased expression of miRNA-29a-3p found in } \\
\text { AAA-mimic cells with increased cellular viability and } \\
\text { significant pathological apoptosis. Further, when the } \\
\text { expression of miRNA-29a-3p was downregulated, it } \\
\text { reduced the cell viability of AAA cells. PTEN was } \\
\text { and tensin homolog (PTEN) }\end{array}$ \\
& $\begin{array}{l}\text { directly targeted by miRNA-29a-3p so as to regulate } \\
\text { the AAA progression. Thus, PTEN was found to } \\
\text { strengthen the proliferation effect of miRNA-29a-3p in } \\
\text { AAA cells. }\end{array}$ \\
\hline
\end{tabular}

Table 2. Biomarkers and compounds in EVAR (treated disease).

\begin{tabular}{|c|c|c|}
\hline Biomarker/Compound & Biological Effect and Clinical Importance & Reference \\
\hline \multirow[b]{2}{*}{ Cystatin C } & $\begin{array}{l}\text { Early marker of renal failure-significant increase of Cystatin C } 24 \text { h } \\
\text { after EVAR and for } 12 \text { months. }\end{array}$ & {$[9]$} \\
\hline & $\begin{array}{l}\text { Cystatin C levels in endovascular aneurysm repair patients } \\
\text { significantly increased post- operatively and restored to values } \\
\text { comparable to baseline at the discharge. }\end{array}$ & {$[55]$} \\
\hline $\begin{array}{l}\text { Platelet count and markers of platelet activation } \\
\text { (CD-62P; CD36) }\end{array}$ & $\begin{array}{l}\text { Significant reduction in PLT count and increase in PLT activation at } \\
\text { the immediate postoperative period }\end{array}$ & {$[56,57]$} \\
\hline Genetic features (MSN, PSMB10, and STIM1) & $\begin{array}{l}\text { Three genes (MSN, PSMB10, and STIM1) are downregulated in } \\
\text { AAA compared with controls; EIF3G, SIVA, PUF60, CYC1, FIBP, } \\
\text { and CARD8 were downregulated post-EVAR. } \\
\text { Those genes are involved in: regulation of apoptosis, proteolysis, } \\
\text { the electron transport chain, leukocyte migration, and the humoral } \\
\text { immune response }\end{array}$ & {$[24]$} \\
\hline $\begin{array}{l}\text { 18F-fluorodeoxyglucose (FDG) detected with } \\
\text { PET/CT; D-dimer }\end{array}$ & $\begin{array}{l}\text { Patients who developed endoleak had a significantly higher SUVr } \\
\text { compared to patients who did not develop endoleak. The SUVr was } \\
\text { significantly higher in the group of patients with sac growth } \\
\text { compared to patients with decreased AAA diameter. Quantitative } \\
\text { analysis showed that sac growth and SUVr were significantly } \\
\text { higher in the presence of endoleak after EVAR. D-dimer was } \\
\text { significantly increased in patients with both endoleak and positive } \\
\text { PET/CT in the post-EVAR group. }\end{array}$ & {$[58]$} \\
\hline \multirow[t]{2}{*}{$\begin{array}{l}\text { Matrix metalloproteinase and tissue inhibitors: MMP-2, } \\
\text { MMP-9 (Pro and activate), TIMP-1, TIMP-2 }\end{array}$} & $\begin{array}{l}\text { Inguinal fascial tissue proMMP-9 significantly predicted } \\
\text { late endoleak. }\end{array}$ & {$[59,60]$} \\
\hline & $\begin{array}{l}\text { ProMMP-9 and active MMP-9 biomarkers are significantly } \\
\text { associated with late endoleak. }\end{array}$ & {$[61,62]$} \\
\hline Osteopontin (OPN) and osteoprotegerin (OPG) & $\begin{array}{l}\text { OPN (a calcification inhibitor) values are associated with aneurysm } \\
\text { presence (more expressed in AAA group than in the control group, } \\
\text { hernia pts); OPN values increase after AAA repair, independently } \\
\text { of the type of repair. }\end{array}$ & [63] \\
\hline Fibrinogen degradation product (FDP) & $\begin{array}{l}\text { A change in FDP of } 3.1 \mathrm{mg} / \mathrm{mL} \text { was the optimal cutoff point for } \\
\text { predicting the presence of an endoleak after EVAR }\end{array}$ & [64] \\
\hline \multirow[t]{2}{*}{ Albumin } & $\begin{array}{l}\text { Preoperative hypoalbuminemia is associated with increased } \\
\text { postoperative morbidity and mortality in a severity-dependent } \\
\text { manner among patients undergoing OAR or EVAR }\end{array}$ & {$[65]$} \\
\hline & $\begin{array}{l}\text { Preoperative hypoalbuminemia is associated with increased } \\
\text { postoperative mortality in pts after FEVAR }\end{array}$ & {$[66]$} \\
\hline Fibrinogen & $\begin{array}{l}\text { the difference in fibrinogen levels (baseline to } 24 \mathrm{~h} \text { post-procedure) } \\
\text { were significantly higher in patients with endoleaks }\end{array}$ & {$[6,67]$} \\
\hline \multirow{3}{*}{ Neutrophil-to-lymphocyte ratio (NLR) } & $\begin{array}{l}\text { Preop NLR > } 3 \text { was independently associated with lower survival } \\
\text { rates at 2-years }\end{array}$ & {$[68]$} \\
\hline & $\begin{array}{l}\text { NLR postoperative value of } 9.9 \text { PLR postoperative value of } 22.8 \\
\text { were associated with the occurrence of AKI after EVAR }\end{array}$ & [69] \\
\hline & $\begin{array}{l}\text { High preoperative level of NLR }(>3.6) \text { was significantly associated } \\
\text { with higher rates of death at } 5 \text { years as well as higher rates of } \\
\text { reinterventions at } 30 \text { days, } 1 \text { year and } 5 \text { years. }\end{array}$ & [70] \\
\hline
\end{tabular}


Table 2. Cont.

\begin{tabular}{|c|c|c|}
\hline Biomarker/Compound & Biological Effect and Clinical Importance & Reference \\
\hline \multirow{2}{*}{$\begin{array}{l}\text { Routine blood tests, white blood cell (WBC), C-reactive } \\
\text { protein }(\mathrm{CRP}), \text { procalcitonin }(\mathrm{PCT})\end{array}$} & $\begin{array}{l}\text { WBC and CRP revealed that inflammatory markers were } \\
\text { significantly enhanced as the volume of mural thrombus increased }\end{array}$ & {$[71,72]$} \\
\hline & $\begin{array}{l}\text { High C-reactive protein, high WBC and low postoperative } \\
\text { procalcitonin are associated with post-implantation syndrome }\end{array}$ & {$[73]$} \\
\hline miRNA & $\begin{array}{l}\text { hyperexpression of miRNA-1281 in patients with AAA and a } \\
\text { significant reduction of it after EVAR } \\
\text { miRNA- } 1281 \text { presents a significant reduction in patients with no } \\
\text { follow-up complications }\end{array}$ & {$[8]$} \\
\hline $\begin{array}{l}\text { Urokinase plasminogen activator (suPAR), endothelin } \\
\text { (ET)-1, tumour necrosis factor (TNF)-a, interleukin } \\
\text { (IL)-6, IgM antibodies against phosphorylcholine } \\
\text { (IgM anti-PC) }\end{array}$ & $\begin{array}{l}\text { SuPAR }(p<0.001) \text {, ET-1 }(p=0.003) \text { and IL- } 6(p=0.02) \text { increased } \\
\text { whereas IgM anti-PC decreased }(p<0.001) \text { after EVAR }\end{array}$ & [74] \\
\hline $\begin{array}{l}\text { Neutrophil gelatin-associated lipocalin (NGAL), } \\
\text { interleukin } 18 \text { (IL-18), and retinol-binding protein } \\
\text { (urine levels) }\end{array}$ & $\begin{array}{l}\text { A significant rise in levels of NGAL and IL-18 precedes the } \\
\text { significant rise in Serum creatinine in pts with AKI after EVAR }\end{array}$ & {$[75,76]$} \\
\hline $\begin{array}{l}\text { Urinary liver-type fatty-acid-binding pro- tein } \\
\text { (L-FABP) }\end{array}$ & $\begin{array}{l}\text { A significant rise in level of urinary L-FABP precedes the rise of } \\
\text { serum creatinine in pts with AKI after EVAR }\end{array}$ & {$[77,78]$} \\
\hline High-mobility group box 1 (HMGB-1) & $\begin{array}{l}\text { Serum HMGB-1: intracellular regulator of gene transcription and } \\
\text { promotes secretion of several inflammatory cytokines. Serum } \\
\text { HMGB-1 levels in AAA patients were significantly higher than in } \\
\text { healthy controls; the serum HMGB-1 levels in both the EVAR group } \\
\text { and the OAR group were significantly decreased from baseline at } \\
\text { both } 3 \text { months and } 1 \text { year after surgery }\end{array}$ & [79] \\
\hline Urinary Cystatin C (uCysC) & $\begin{array}{l}\text { High postoperative level uCysC precedes the rise of serum } \\
\text { creatinine in pts with AKI after EVAR or OR }\end{array}$ & [80] \\
\hline $\begin{array}{l}\text { Tumor necrosis factor- } \alpha \text { converting enzyme (TACE), } \\
\text { Notch-1 }\end{array}$ & $\begin{array}{l}\text { TACE and Notch1 concentrations were higher in patients with } \\
\text { endoleak than in those without endoleak, } 6 \text { months after EVAR }\end{array}$ & [81] \\
\hline Intraluminal thrombus (ILT) & Absence of ILT is a significant predictor of type II endoleak & [82] \\
\hline $\begin{array}{l}\text { Serum IL-1- } \alpha \text {, IL-1 } \beta, \text { IL-4, IL-6, IL- } 8, \text { IL-10, IFN- } \gamma \text {, } \\
\text { IP-10, MCP-1, TNF- } \alpha \text {, and TNF- } \beta\end{array}$ & Significant decrease of IL- $1 \alpha, 6$ months after EVAR & [83] \\
\hline Aspartate transaminase to platelet ratio index (APRI) & $\begin{array}{l}\text { Significant increase in morbidity and mortality in pts with liver } \\
\text { fibrosis after EVAR }\end{array}$ & {$[84,85]$} \\
\hline
\end{tabular}

Table 3. Biomarkers and compounds in thoracoabdominal aortic aneurysms (untreated disease).

\begin{tabular}{|c|c|c|}
\hline Biomarker/Compound & Biological Effect and Clinical Importance & Reference \\
\hline \multirow{4}{*}{ Genetic features } & $\begin{array}{l}\text { Three genes (MSN, PSMB10, and STIM1) are downregulated in AAA } \\
\text { compared with controls. Those genes are involved in: regulation of } \\
\text { apoptosis, proteolysis, the electron transport chain, leukocyte migration, } \\
\text { and the humoral immune response. }\end{array}$ & {$[24]$} \\
\hline & $\begin{array}{l}\text { ALOX5, PTGIS, CX3CL1 genes are potentially related with diagnosis } \\
\text { of AAA. }\end{array}$ & [23] \\
\hline & $\begin{array}{l}\text { Gene expression profiles allowed to select new potential cytometry } \\
\text { markers: CNN1, MYH10, MYOCD, ENG, ICAM2, TEK. }\end{array}$ & [86] \\
\hline & $\begin{array}{l}120 \text { genes were differentially expressed in AAA. In particular genes } \\
\text { associated with inflammatory responses and nuclear-transcribed } \\
\text { mRNA catabolic process. The expression levels of IL6 correlated } \\
\text { positively with RPL7A and negatively with RPL21. The expression of } \\
\text { RPL21 and RPL7A was downregulated, whereas that of IL6 was } \\
\text { upregulated in AAA. }\end{array}$ & {$[87]$} \\
\hline
\end{tabular}


Table 3. Cont.

\begin{tabular}{ll}
\hline Biomarker/Compound & Biological Effect and Clinical Importance \\
\hline & $\begin{array}{l}\text { miRNAs are small (19-24 nucleotides) and highly conserved } \\
\text { non-coding RNAs involved in gene regulation; are involved in several } \\
\text { processes, such as cellular differentiation, apoptosis, or tumorigenesis. }\end{array}$ \\
\cline { 2 - 3 } & $\begin{array}{l}\text { miR-193b-3p, 125b-5p, 150-5p are potentially related with diagnosis of } \\
\text { AAA hsa-miR-30a-GNG2 and hsa-miR-15b-ACSS2 interaction pairs } \\
\text { may represent novel mechanisms for explaining the pathogenesis } \\
\text { miRNAs }\end{array}$ \\
\cline { 3 - 3 }
\end{tabular}

In AAA tissue, six miRNAs (miR-1, miR-27b-3p, miR-29b-3p, miR-133a-3p, miR-133b, and miR-195-5p) were underexpressed from 1.6 to 4.8 times and four miRNAs (miR-146a-5p, miR-21-5p, miR-144-3p, and miR-103a-3p) were overexpressed from 1.3 to 7.2 times, suggesting their involvement in a common regulatory mechanism

A total of 31 miRNAs and 51 genes were selected as the most promising biomarkers of diagnosis of AAA.

PTX3 was upregulated in AAA and colocalized with inflammatory infiltrates.

Pentraxin 3 (PTX3) Increased serum CAR was found to be an independent predictor of the presence of AAA

C-reactive protein (CRP)-to-albumin ratio (CAR)

Gal-1 is highly induced and contributes to AAA by enhancing matrix degradation activity and inflammatory responses in experimental model; The pathological link between Gal-1 and AAA is also observed in human patients

Galectin-1

Gal-3 regulates chemotaxis and inflammation; has been reported as a prognostic marker for cardiovascular disease as it is linked to myocardial fibrosis, tissue remodeling, and heart failure development.

Galectin-3 Circulating Gal-3 levels were significantly correlated with aortic diameter in a concentration-dependent manner.

Higher plasma Gal-3 concentrations may be a useful biomarker of AAA progression

Serum calprotectin

Serum calprotectin levels in AAA patients were three times higher than in healthy subjects

TLRs are type I transmembrane proteins expressed on various immune cells, which recognize molecular patterns unique to pathogens or endogenous molecules released from dying or injured cells Heterozygous genotypes of the TLR2 2029C/T and TLR3 1377C/T and polymorphisms (SNPs) 27C / A SNPs may serve as genetic biomarkers of AAA incidence

PRDX are a ubiquitous family of thiol- specific antioxidant enzymes that control the levels of intracellular peroxide, which is involved in oxidative stress and signal transduction. PRDX2 plays a role as a negative regulator of the pathological process

Peroxiredoxins (PRDX) of AAA

mCRP induces an inflammatory response by monocyte activation and reactive oxygen species formation to exacerbate tissue damage. AAA showed a characteristic deposition of $\mathrm{mCRP}$, and multiple potentially pathologic signaling pathways were upregulated in AAA cases with strong CRP immunopositivity (pathways associated with atherosclerosis, acute phase response, complement system, immune system, and coagulation)

Monomeric form of C-reactive protein (mCRP)

3 proteins that are present in ILT, released by ILT and differs between

Proteins released by intramural thrombus (ILT) fast and slow growth AAAs. Plasma Attractin correlates significantly with future AAA growth

GZMK, a proinflammatory member of granzyme family, was first discovered in human lymphokine-activated killer cells, and mainly expressed by cytotoxic lymphocytes and monocyte/macrophage cells. infiltrated immune cells in AAA tissues and their associated marker genes: GZMK, CCL5, GZMA, CD2, EOMES, CD247, CD2, CD6, RASGRP1, and CD48 elevated GZMK expression both in serum and tissues is correlated with the presence of AAA, and serum GZMK may be a useful non-invasive marker that helps to identify AAA and its rupture risk 
Table 3. Cont.

\begin{tabular}{|c|c|c|}
\hline Biomarker/Compound & Biological Effect and Clinical Importance & Reference \\
\hline Low molecular weight metabolites & $\begin{array}{l}\text { four amino acids (histidine, asparagine, leucine, isoleucine) and four } \\
\text { phosphatidylcholines (PC.ae.C } 34.3 \text {, PC.aa.C34.2, PC.ae.C } 38.0 \text {, } \\
\text { lysoPC.a.C18.2) were found to be significantly lower after adjustment } \\
\text { for confounders among the AAA patients compared with the controls }\end{array}$ & {$[98]$} \\
\hline Dipeptidyl peptidase-4 (DPP4)-inhibitors & $\begin{array}{l}\text { Dipeptidyl peptidase-4 (DPP4 a.k.a. CD26) is a serine protease that } \\
\text { exists as a membrane bound cell surface peptidase, and as a soluble } \\
\text { form in the circulation. } \\
\text { DPP } 4 \text { gene expression is correlated with the expression of genes related } \\
\text { to typical AAA processes and the protein was expressed by macro- } \\
\text { phages, T-cells, B-cells and SMCs in aneurysm tissue }\end{array}$ & {$[99]$} \\
\hline Long noncoding RNAs (lncRNAs) & $\begin{array}{l}\text { lncRNAs have the potential to regulate the expression of genes at the } \\
\text { epigenetic, transcriptional, and posttranscriptional levels and play an } \\
\text { important role in physiological process. Microarray profile analysis and } \\
\text { validation of significantly expressed lncRNA between patients with } \\
\text { AAA and the control group }\end{array}$ & [100] \\
\hline Cystatin B & $\begin{array}{l}\text { Growth/differentiation factor } 15 \text { and cystatin B had the best ability to } \\
\text { discriminate AAA from non-AAA. Higher baseline levels of } \\
\text { myeloperoxidase were significantly associated with faster abdominal } \\
\text { aortic aneurysm growth }\end{array}$ & {$[101]$} \\
\hline Kallikrein-1 & $\begin{array}{l}\text { Serine protease that generates bradykinin, promoting inflammation. } \\
\text { Kallikrein- } 1 \text { blocking antibody reduced levels of cyclooxygenase- } 2 \text { and } \\
\text { secretion of prostaglandin E2 and active matrix metalloproteinase } 2 \text { and } \\
\text { matrix metalloproteinase } 9 \text { from human AAA explants and vascular } \\
\text { smooth muscle cells exposed to activated neutrophils }\end{array}$ & [32] \\
\hline $\begin{array}{l}\text { Serum lipid peroxidation products: malondialdehyde } \\
\text { (MDA), lipid hydroperoxide (LPO), and glutathione } \\
\text { peroxidase (GSH-Px) }\end{array}$ & $\begin{array}{l}\text { the serum MDA and LPO among AAA cases were remarkably } \\
\text { increased compared with those from the normal patients. Inversely, } \\
\text { serum GSH-Px was significantly decreased in patients with AAA } \\
\text { compared to the control group. Moreover, serum MDA level was } \\
\text { significantly increased in cases with rupture AAA compared to those in } \\
\text { selective AAA cases. Serum MDA may serve as the candidate } \\
\text { biomarker for diagnosis of AAA and accurate identification of increased } \\
\text { risks of AAA rupture. }\end{array}$ & {$[102]$} \\
\hline Ankle brachial index (ABI) & $\begin{array}{l}\text { Logistical regression analysis revealed a statistically significant negative } \\
\text { association between initial monophasic posterior tibial artery waveform } \\
\text { and abdominal aortic aneurysm presence in patients with ABI }>0.9 \text {. }\end{array}$ & [103] \\
\hline Fibroblast growth factor 21 (FGF21) & $\begin{array}{l}\text { FGF21 is a peptide hormone maintaining the homeostasis of glucose, } \\
\text { lipid, and energy balance, which belongs to the human FGF } \\
\text { superfamily that has crucial roles in a myriad of biological processes. } \\
\text { FGF21 was statistically higher in patients with AAA than in control } \\
\text { subjects. The protein levels of } \beta \text {-klotho (an essential co-receptor of } \\
\text { FGF21) in abdominal aorta of AAA were found significantly lower than } \\
\text { in control group. }\end{array}$ & {$[104]$} \\
\hline
\end{tabular}

\section{Future Directions}

Despite the great interest and the flourishing literature in recent years, at present, the use of circulating biomarkers to detect complications of EVAR is still limited in clinical practice due to restricted availability and lack of recommendations from guidelines. To overcome those limitations, the methodology used to study the development and progression of aortic aneurysm should be translated into the EVAR scenario to support the use of biomarkers in the early diagnosis of complications. A potential first-in-clinic biomarker for EVAR would improve surveillance programs after hospital discharge, with tailored use of CT scan. Derivation and validation of a predictive model, according to age and sex, could be performed with a tailored registry analysis, with a synthetic evaluation of the most promising biomarkers such as IL-6, IL-18, cystatin C, MMP-9, and NGAL, similarly to point-of-care testing for platelet function.

An accurate analysis of the postoperative immune response will help in creating a more predictive biomarker panel for post-procedural morbidity. Future large prospective studies are required to identify the exact mechanisms of the cytokine interaction in the 
post-EVAR setting. Similarly, MMP-9 testing sensitivity and specificity should be evaluated in a real-life cohort before being considered as a surveillance test. Specific serum biomarkers could potentially form the basis of a tailored follow-up for patients with AAA or post-EVAR. Larger prospective trials are required to establish and evaluate prognostic models with highest values with these markers.

\section{Conclusions}

Circulating IL-6 is a marker of inflammatory reaction after EVAR and might act as a useful predictor of postoperative morbidity. Cystatin $\mathrm{C}$ is a promising early marker of post-procedural acute kidney injury after EVAR. Plasma MMP-9 concentration after three months from EVAR might help in detecting post-procedural endoleak. miRNAs are promising, but still limited in their clinical practice. Biomarkers for postoperative renal failure after EVAR are extremely debated in the literature, with some having strong references (NGAL, cystatin $\mathrm{C}$ ) and others having weaker data to support their use (retinol binding protein, IL-18, N-acetyle-b-D-glocosaminidase).

In the setting of AAA, biomarkers have been more extensively investigated. Genetic factors and specific miRNA showed great association with AAA development and progression. Considering point-of-care testing, Galectin-1 and Galectin-3 might be extremely useful in clinical practice as biomarker of AAA progression, while Granzyme K and malondialdehyde are potential indicators of AAA rupture.

Author Contributions: Conceptualization, F.S. (Francesco Stilo), V.C., A.N.; methodology, F.S. (Francesco Stilo), V.C., A.N., T.G., N.M; data curation, F.S. (Francesco Stilo), V.C., A.N., M.J., E.V.; writing-original draft preparation, F.S. (Francesco Stilo), V.C., M.J., E.V., T.G., N.M., F.A.C.; writingreview and editing, A.N., M.C.; supervision, M.C., F.S. (Francesco Spinelli). All authors have read and agreed to the published version of the manuscript.

Funding: This research received no external funding.

Institutional Review Board Statement: The study was conducted according to the guidelines of the Declaration of Helsinki. Not applicable.

Informed Consent Statement: Not applicable.

Data Availability Statement: PubMed: https:/ / pubmed.ncbi.nlm.nih.gov/ (accessed on 1 November 2021); Scopus: https:/ / www.scopus.com/home.uri (accessed on 1 November 2021).

Acknowledgments: We would like to thank our friend and colleague David Rose for language editing.

Conflicts of Interest: The authors declare no conflict of interest.

\section{References}

1. $\mathrm{Ng}$, E.; Morris, D.R.; Golledge, J. The association between plasma matrix metalloproteinase-9 concentration and endoleak after endovascular aortic aneurysm repair: A meta-analysis. Atherosclerosis 2015, 242, 535-542. [CrossRef]

2. Karaolanis, G.; Williams, Z.F.; Bakoyiannis, C.; Hadjis, D.; Cox, M.W.; Moris, D. The Clinical Utility and Assessment of Renal Biomarkers in Acute Kidney Injury After Abdominal Endovascular Aneurysm Repair. A Systematic Review. Curr. Pharm. Des. 2019, 25, 4695-4701. [CrossRef]

3. Tsilimigras, D.I.; Sigala, F.; Karaolanis, G.; Ntanasis-Stathopoulos, I.; Spartalis, E.; Spartalis, M.; Patelis, N.; Papalampros, A.; Long, C.; Moris, D. Cytokines as biomarkers of inflammatory response after open versus endovascular repair of abdominal aortic aneurysms: A systematic review. Acta Pharmacol. Sin. 2018, 39, 1164-1175. [CrossRef]

4. Antoniou, G.A.; Georgiadis, G.S.; Antoniou, S.A.; Murray, D.; Smyth, J.V.; Serracino-Inglott, F.; Paraskevas, K.I. Plasma matrix metalloproteinase 9 levels may predict endoleaks after endovascular aortic aneurysm repair. Angiology 2013, 64, 49-56. [CrossRef]

5. Huddle, M.G.; Schlosser, F.J.; Dewan, M.C.; Indes, J.; Muhs, B.E. Can laboratory tests predict the prognosis of patients after endovascular aneurysm repair? Current status and future directions. Vascular 2009, 17, 129-137. [CrossRef]

6. Kapetanios, D.M.; Karkos, C.D.; Papazoglou, K.O. Changes in circulating markers of coagulation and fibrinolysis after EVAR. Int. Angiol. A J. Int. Union Angiol. 2018, 37, 444-450. [CrossRef]

7. Davies, R.S.; Abdelhamid, M.; Wall, M.L.; Vohra, R.K.; Bradbury, A.W.; Adam, D.J. Coagulation, fibrinolysis, and platelet activation in patients undergoing open and endovascular repair of abdominal aortic aneurysm. J. Vasc. Surg. 2011, 54, 865-878. [CrossRef] 
8. Missae, L.; Rossoni, B.; Tenorio, E.J.R.; Ribeiro, M.S.; Tirapelli, D.; Joviliano, E.E. Expression of MicroRNA-1281, C-Reactive Protein, and Renal Function in Individuals with Abdominal Aortic Aneurysm and their Clinical Correlation after Endovascular Repair. Braz. J. Cardiovasc. Surg. 2021, 36, 301-307. [CrossRef] [PubMed]

9. Abdelhamid, M.F.; Davies, R.S.; Vohra, R.K.; Adam, D.J.; Bradbury, A.W. Assessment of renal function by means of cystatin C following standard and fenestrated endovascular aneurysm repair. Ann. Vasc. Surg. 2013, 27, 708-713. [CrossRef] [PubMed]

10. Wu, J.; Wang, W.; Chen, Z.; Xu, F.; Zheng, Y. Proteomics applications in biomarker discovery and pathogenesis for abdominal aortic aneurysm. Expert Rev. Proteom. 2021, 18, 305-314. [CrossRef] [PubMed]

11. Bylund, D.; Henriksson, A.E. Proteomic approaches to identify circulating biomarkers in patients with abdominal aortic aneurysm. Am. J. Cardiovasc. Dis. 2015, 5, 140-145. [CrossRef]

12. Urbonavicius, S.; Urbonaviciene, G.; Honore, B.; Henneberg, E.W.; Vorum, H.; Lindholt, J.S. Potential circulating biomarkers for abdominal aortic aneurysm expansion and rupture-A systematic review. Eur. J. Vasc. Endovasc. Surg. Off. J. Eur. Soc. Vasc. Surg. 2008, 36, 273-280. [CrossRef] [PubMed]

13. Stather, P.W.; Sidloff, D.A.; Dattani, N.; Gokani, V.J.; Choke, E.; Sayers, R.D.; Bown, M.J. Meta-analysis and meta-regression analysis of biomarkers for abdominal aortic aneurysm. Br. J. Surg. 2014, 101, 1358-1372. [CrossRef]

14. Nana, P.; Dakis, K.; Brodis, A.; Spanos, K.; Kouvelos, G. Circulating Biomarkers for the Prediction of Abdominal Aortic Aneurysm Growth. J. Clin. Med. 2021, 10, 1718. [CrossRef]

15. Moris, D.; Mantonakis, E.; Avgerinos, E.; Makris, M.; Bakoyiannis, C.; Pikoulis, E.; Georgopoulos, S. Novel biomarkers of abdominal aortic aneurysm disease: Identifying gaps and dispelling misperceptions. BioMed Res. Int. 2014, 2014, 925840. [CrossRef] [PubMed]

16. Li, Y.; Yang, D.; Zheng, Y. Challenges of applying circulating biomarkers for abdominal aortic aneurysm progression. Exp. Biol. Med. 2021, 246, 1054-1059. [CrossRef]

17. Groeneveld, M.E.; Meekel, J.P.; Rubinstein, S.M.; Merkestein, L.R.; Tangelder, G.J.; Wisselink, W.; Truijers, M.; Yeung, K.K. Systematic Review of Circulating, Biomechanical, and Genetic Markers for the Prediction of Abdominal Aortic Aneurysm Growth and Rupture. J. Am. Heart Assoc. 2018, 7, e007791. [CrossRef] [PubMed]

18. Davis, F.M.; Rateri, D.L.; Daugherty, A. Abdominal aortic aneurysm: Novel mechanisms and therapies. Curr. Opin. Cardiol. 2015, 30, 566-573. [CrossRef]

19. Jalalzadeh, H.; Indrakusuma, R.; Planken, R.N.; Legemate, D.A.; Koelemay, M.J.; Balm, R. Inflammation as a Predictor of Abdominal Aortic Aneurysm Growth and Rupture: A Systematic Review of Imaging Biomarkers. Eur. J. Vasc. Endovasc. Surg. Off. J. Eur. Soc. Vasc. Surg. 2016, 52, 333-342. [CrossRef]

20. Li, T.; Lv, Z.; Jing, J.J.; Yang, J.; Yuan, Y. Matrix metalloproteinase family polymorphisms and the risk of aortic aneurysmal diseases: A systematic review and meta-analysis. Clin. Genet. 2018, 93, 15-32. [CrossRef]

21. Martin-Ventura, J.L.; Martinez-Lopez, D.; Roldan-Montero, R.; Gomez-Guerrero, C.; Blanco-Colio, L.M. Role of complement system in pathological remodeling of the vascular wall. Mol. Immunol. 2019, 114, 207-215. [CrossRef] [PubMed]

22. Klopf, J.; Brostjan, C.; Neumayer, C.; Eilenberg, W. Neutrophils as Regulators and Biomarkers of Cardiovascular Inflammation in the Context of Abdominal Aortic Aneurysms. Biomedicines 2021, 9, 1236. [CrossRef]

23. Araujo, N.N.F.; Lin-Wang, H.T.; Germano, J.F.; Farsky, P.S.; Feldman, A.; Rossi, F.H.; Izukawa, N.M.; Higuchi, M.L.; Savioli Neto, F.; Hirata, M.H.; et al. Dysregulation of microRNAs and target genes networks in human abdominal aortic aneurysm tissues. PLoS ONE 2019, 14, e0222782. [CrossRef]

24. Butt, H.Z.; Sylvius, N.; Salem, M.K.; Wild, J.B.; Dattani, N.; Sayers, R.D.; Bown, M.J. Microarray-based Gene Expression Profiling of Abdominal Aortic Aneurysm. Eur. J. Vasc. Endovasc. Surg. Off. J. Eur. Soc. Vasc. Surg. 2016, 52, 47-55. [CrossRef]

25. Plana, E.; Galvez, L.; Medina, P.; Navarro, S.; Fornes-Ferrer, V.; Panadero, J.; Miralles, M. Identification of Novel microRNA Profiles Dysregulated in Plasma and Tissue of Abdominal Aortic Aneurysm Patients. Int. J. Mol. Sci. 2020, 21, 4600. [CrossRef]

26. Zalewski, D.P.; Ruszel, K.P.; Stepniewski, A.; Galkowski, D.; Bogucki, J.; Kolodziej, P.; Szymanska, J.; Plachno, B.J.; Zubilewicz, T.; Feldo, M.; et al. Identification of Transcriptomic Differences between Lower Extremities Arterial Disease, Abdominal Aortic Aneurysm and Chronic Venous Disease in Peripheral Blood Mononuclear Cells Specimens. Int. J. Mol. Sci. 2021, $22,3200$. [CrossRef]

27. Zalewski, D.P.; Ruszel, K.P.; Stepniewski, A.; Galkowski, D.; Bogucki, J.; Komsta, L.; Kolodziej, P.; Chmiel, P.; Zubilewicz, T.; Feldo, M.; et al. Dysregulation of microRNA Modulatory Network in Abdominal Aortic Aneurysm. J. Clin. Med. 2020, 9, 1974. [CrossRef] [PubMed]

28. Blassova, T.; Tonar, Z.; Tomasek, P.; Hosek, P.; Hollan, I.; Treska, V.; Molacek, J. Inflammatory cell infiltrates, hypoxia, vascularization, pentraxin 3 and osteoprotegerin in abdominal aortic aneurysms-A quantitative histological study. PLoS ONE 2019, 14, e0224818. [CrossRef]

29. Chiang, M.T.; Chen, I.M.; Hsu, F.F.; Chen, Y.H.; Tsai, M.S.; Hsu, Y.W.; Leu, H.B.; Huang, P.H.; Chen, J.W.; Liu, F.T.; et al. Gal-1 (Galectin-1) Upregulation Contributes to Abdominal Aortic Aneurysm Progression by Enhancing Vascular Inflammation. Arterioscler. Thromb. Vasc. Biol. 2021, 41, 331-345. [CrossRef]

30. Hauzer, W.; Ferenc, S.; Rosinczuk, J.; Gnus, J. The Role of Serum Calprotectin as a New Marker in Abdominal Aortic AneurysmsA Preliminary Report. Curr. Pharm. Biotechnol. 2021, 22, 508-513. [CrossRef] [PubMed]

31. Hauzer, W.; Witkiewicz, W.; Gnus, J. Calprotectin and Receptor for Advanced Glycation End Products as a Potential Biomarker in Abdominal Aortic Aneurysm. J. Clin. Med. 2020, 9, 927. [CrossRef] [PubMed] 
32. Moran, C.S.; Biros, E.; Krishna, S.M.; Morton, S.K.; Sexton, D.J.; Golledge, J. Kallikrein-1 Blockade Inhibits Aortic Expansion in a Mouse Model and Reduces Prostaglandin E2 Secretion From Human Aortic Aneurysm Explants. J. Am. Heart Assoc. 2021, 10, e019372. [CrossRef]

33. Li, T.; Yang, C.; Jing, J.; Sun, L.; Yuan, Y. Granzyme K-A novel marker to identify the presence and rupture of abdominal aortic aneurysm. Int. J. Cardiol. 2021, 338, 242-247. [CrossRef]

34. Wu, Z.Y.; Trenner, M.; Boon, R.A.; Spin, J.M.; Maegdefessel, L. Long noncoding RNAs in key cellular processes involved in aortic aneurysms. Atherosclerosis 2020, 292, 112-118. [CrossRef]

35. Raffort, J.; Lareyre, F.; Clement, M.; Mallat, Z. Micro-RNAs in abdominal aortic aneurysms: Insights from animal models and relevance to human disease. Cardiovasc. Res. 2016, 110, 165-177. [CrossRef]

36. Kumar, S.; Boon, R.A.; Maegdefessel, L.; Dimmeler, S.; Jo, H. Role of Noncoding RNAs in the Pathogenesis of Abdominal Aortic Aneurysm. Circ. Res. 2019, 124, 619-630. [CrossRef]

37. Borek, A.; Drzymala, F.; Botor, M.; Augusciak-Duma, A.M.; Sieron, A.L. Roles of microRNAs in abdominal aortic aneurysm pathogenesis and the possibility of their use as biomarkers. Kardiochirurgia I Torakochirurgia Pol. = Pol. J. Cardio-Thorac. Surg. 2019, 16, 124-127. [CrossRef] [PubMed]

38. Iyer, V.; Rowbotham, S.; Biros, E.; Bingley, J.; Golledge, J. A systematic review investigating the association of microRNAs with human abdominal aortic aneurysms. Atherosclerosis 2017, 261, 78-89. [CrossRef]

39. Knappich, C.; Spin, J.M.; Eckstein, H.H.; Tsao, P.S.; Maegdefessel, L. Involvement of Myeloid Cells and Noncoding RNA in Abdominal Aortic Aneurysm Disease. Antioxid. Redox Signal. 2020, 33, 602-620. [CrossRef] [PubMed]

40. Hovsepian, D.M.; Ziporin, S.J.; Sakurai, M.K.; Lee, J.K.; Curci, J.A.; Thompson, R.W. Elevated plasma levels of matrix metalloproteinase-9 in patients with abdominal aortic aneurysms: A circulating marker of degenerative aneurysm disease. J. Vasc. Interv. Radiol. JVIR 2000, 11, 1345-1352. [CrossRef]

41. LeMaire, S.A.; Wang, X.; Wilks, J.A.; Carter, S.A.; Wen, S.; Won, T.; Leonardelli, D.; Anand, G.; Conklin, L.D.; Wang, X.L.; et al. Matrix metalloproteinases in ascending aortic aneurysms: Bicuspid versus trileaflet aortic valves. J. Surg. Res. 2005, 123, 40-48. [CrossRef] [PubMed]

42. Koullias, G.J.; Ravichandran, P.; Korkolis, D.P.; Rimm, D.L.; Elefteriades, J.A. Increased tissue microarray matrix metalloproteinase expression favors proteolysis in thoracic aortic aneurysms and dissections. Ann. Thorac. Surg. 2004, 78, 2106-2110. [CrossRef]

43. Ramirez, F.; Rifkin, D.B. Extracellular microfibrils: Contextual platforms for TGFbeta and BMP signaling. Curr. Opin. Cell Biol. 2009, 21, 616-622. [CrossRef] [PubMed]

44. Steffensen, L.B.; Stubbe, J.; Lindholt, J.S.; Beck, H.C.; Overgaard, M.; Bloksgaard, M.; Genovese, F.; Holm Nielsen, S.; Tha, M.L.T.; Bang-Moeller, S.K.; et al. Basement membrane collagen IV deficiency promotes abdominal aortic aneurysm formation. Sci. Rep. 2021, 11, 12903. [CrossRef] [PubMed]

45. Ostberg, N.P.; Zafar, M.A.; Ziganshin, B.A.; Elefteriades, J.A. The Genetics of Thoracic Aortic Aneurysms and Dissection: A Clinical Perspective. Biomolecules 2020, 10, 182. [CrossRef]

46. Schwarze, U.; Schievink, W.I.; Petty, E.; Jaff, M.R.; Babovic-Vuksanovic, D.; Cherry, K.J.; Pepin, M.; Byers, P.H. Haploinsufficiency for one COL3A1 allele of type III procollagen results in a phenotype similar to the vascular form of Ehlers-Danlos syndrome, Ehlers-Danlos syndrome type IV. Am. J. Hum. Genet. 2001, 69, 989-1001. [CrossRef]

47. Neptune, E.R.; Frischmeyer, P.A.; Arking, D.E.; Myers, L.; Bunton, T.E.; Gayraud, B.; Ramirez, F.; Sakai, L.Y.; Dietz, H.C. Dysregulation of TGF-beta activation contributes to pathogenesis in Marfan syndrome. Nat. Genet. 2003, 33, 407-411. [CrossRef]

48. Didangelos, A.; Yin, X.; Mandal, K.; Baumert, M.; Jahangiri, M.; Mayr, M. Proteomics characterization of extracellular space components in the human aorta. Mol. Cell. Proteom. MCP 2010, 9, 2048-2062. [CrossRef]

49. Barallobre-Barreiro, J.; Loeys, B.; Mayr, M.; Rienks, M.; Verstraeten, A.; Kovacic, J.C. Extracellular Matrix in Vascular Disease, Part 2/4: JACC Focus Seminar. J. Am. Coll. Cardiol. 2020, 75, 2189-2203. [CrossRef]

50. Yin, X.; Wanga, S.; Fellows, A.L.; Barallobre-Barreiro, J.; Lu, R.; Davaapil, H.; Franken, R.; Fava, M.; Baig, F.; Skroblin, P.; et al. Glycoproteomic Analysis of the Aortic Extracellular Matrix in Marfan Patients. Arterioscler. Thromb. Vasc. Biol. 2019, 39, $1859-1873$. [CrossRef] [PubMed]

51. Eilenberg, W.; Zagrapan, B.; Bleichert, S.; Ibrahim, N.; Knobl, V.; Brandau, A.; Martelanz, L.; Grasl, M.T.; Hayden, H.; Nawrozi, P.; et al. Histone citrullination as a novel biomarker and target to inhibit progression of abdominal aortic aneurysms. Transl. Res. J. Lab. Clin. Med. 2021, 233, 32-46. [CrossRef] [PubMed]

52. Zhou, Y.; Wang, M.; Zhang, J.; Xu, P.; Wang, H. MicroRNA-29a-3p regulates abdominal aortic aneurysm development and progression via direct interaction with PTEN. J. Cell. Physiol. 2020, 235, 9414-9423. [CrossRef]

53. Huang, K.; Wang, Y.; Siu, K.L.; Zhang, Y.; Cai, H. Targeting feed-forward signaling of TGFbeta/NOX4/DHFR/eNOS uncoupling/TGFbeta axis with anti-TGFbeta and folic acid attenuates formation of aortic aneurysms: Novel mechanisms and therapeutics. Redox Biol. 2021, 38, 101757. [CrossRef]

54. Huang, T.; Liu, S.; Liu, R.; Pan, B.; Wang, W. Inhibition of miR-188-5p Suppresses Progression of Experimental Abdominal Aortic Aneurysms. J. Cardiovasc. Pharmacol. 2021, 77, 107-114. [CrossRef] [PubMed]

55. Ilic, N.S.; Opacic, D.; Mutavdzic, P.; Koncar, I.; Dragas, M.; Jovicic, S.; Markovic, M.; Davidovic, L. Evaluation of the renal function using serum Cystatin C following open and endovascular aortic aneurysm repair. Vascular 2018, 26, 132-141. [CrossRef]

56. Arnaoutoglou, E.; Kouvelos, G.; Papa, N.; Karamoutsios, A.; Bouris, V.; Vartholomatos, G.; Matsagkas, M. Platelet activation after endovascular repair of abdominal aortic aneurysm. Vascular 2016, 24, 287-294. [CrossRef] 
57. De Haro, J.; Bleda, S.; Acin, F. C-reactive protein predicts aortic aneurysmal disease progression after endovascular repair. Int. J. Cardiol. 2016, 202, 701-706. [CrossRef] [PubMed]

58. Courtois, A.; Makrygiannis, G.; El Hachemi, M.; Hultgren, R.; Allaire, E.; Namur, G.; Hustinx, R.; Defraigne, J.O.; Sakalihasan, N. Positron Emission Tomography/Computed Tomography Predicts and Detects Complications After Endovascular Repair of Abdominal Aortic Aneurysms. J. Endovasc. Ther. Off. J. Int. Soc. Endovasc. Spec. 2019, 26, 520-528. [CrossRef]

59. Ascoli Marchetti, A.; Pratesi, G.; Di Giulio, L.; Battistini, M.; Massoud, R.; Ippoliti, A. EVAR and OPEN treatment of abdominal aortic aneurysm: What is the role of MMP-9 in the follow-up? J. Med. Vasc. 2017, 42, 21-28. [CrossRef]

60. Georgiadis, G.S.; Antoniou, G.A.; Argyriou, C.; Schoretsanitis, N.; Nikolopoulos, E.; Kapoulas, K.; Lazarides, M.K.; Tentes, I. Correlation of Baseline Plasma and Inguinal Connective Tissue Metalloproteinases and Their Inhibitors With Late High-Pressure Endoleak After Endovascular Aneurysm Repair: Long-term Results. J. Endovasc. Ther. Off. J. Int. Soc. Endovasc. Spec. 2019, 26, 826-835. [CrossRef] [PubMed]

61. Hellenthal, F.A.; Ten Bosch, J.A.; Pulinx, B.; Wodzig, W.K.; de Haan, M.W.; Prins, M.H.; Welten, R.J.; Teijink, J.A.; Schurink, G.W. Plasma levels of matrix metalloproteinase-9: A possible diagnostic marker of successful endovascular aneurysm repair. Eur. $J$. Vasc. Endovasc. Surg. Off. J. Eur. Soc. Vasc. Surg. 2012, 43, 171-172. [CrossRef]

62. Moxon, J.V.; Ng, E.; Lazzaroni, S.M.; Boult, M.; Velu, R.; Fitridge, R.A.; Golledge, J. Circulating biomarkers are not associated with endoleaks after endovascular repair of abdominal aortic aneurysms. J. Vasc. Surg. 2018, 67, 770-777. [CrossRef]

63. Filis, K.; Martinakis, V.; Galyfos, G.; Sigala, F.; Theodorou, D.; Andreadou, I.; Zografos, G. Osteopontin and Osteoprotegerin as Potential Biomarkers in Abdominal Aortic Aneurysm before and after Treatment. Int. Sch. Res. Not. 2014, 2014, 461239. [CrossRef]

64. Ikoma, A.; Nakai, M.; Sato, M.; Sato, H.; Takeuchi, H.; Tanaka, F.; Sanda, H.; Nakata, K.; Minamiguchi, H.; Sonomura, T.; et al. Changes in inflammatory, coagulopathic, and fibrinolytic responses after endovascular repair of an abdominal aortic aneurysm: Relationship between fibrinogen degradation product levels and endoleaks. Jpn. J. Radiol. 2014, 32, 347-355. [CrossRef]

65. Inagaki, E.; Farber, A.; Eslami, M.H.; Kalish, J.; Rybin, D.V.; Doros, G.; Peacock, M.R.; Siracuse, J.J. Preoperative hypoalbuminemia is associated with poor clinical outcomes after open and endovascular abdominal aortic aneurysm repair. J. Vasc. Surg. 2017, 66, 53-63.e51. [CrossRef]

66. Wohlauer, M.; Brier, C.; Kuramochi, Y.; Eagleton, M. Preoperative Hypoalbuminemia is a Risk Factor for Early and Late Mortality in Patients Undergoing Endovascular Juxtarenal and Thoracoabdominal Aortic Aneurysm Repair. Ann. Vasc. Surg. 2017, 42, 198-204. [CrossRef]

67. Kapetanios, D.; Karkos, C.D.; Pliatsios, I.; Mitka, M.; Giagtzidis, I.T.; Konstantinidis, K.; Papazoglou, K.O. Association Between Perioperative Fibrinogen Levels and the Midterm Outcome in Patients Undergoing Elective Endovascular Repair of Abdominal Aortic Aneurysms. Ann. Vasc. Surg. 2019, 56, 202-208. [CrossRef]

68. Lecumberri, E.; Ruiz-Carmona, C.; Mateos, E.; Galarza, A.; Subirana, I.; Clara, A. Prognostic Value of Inflammatory Biomarkers in 5-Year Survival After Endovascular Repair of Abdominal Aortic Aneurysms in a Predominantly Male Cohort: Implications for Practice. World J. Surg. 2021, 45, 1949-1955. [CrossRef] [PubMed]

69. Ntalouka, M.P.; Nana, P.; Kouvelos, G.N.; Stamoulis, K.; Spanos, K.; Giannoukas, A.; Matsagkas, M.; Arnaoutoglou, E. Association of Neutrophil-Lymphocyte and Platelet-Lymphocyte Ratio with Adverse Events in Endovascular Repair for Abdominal Aortic Aneurysm. J. Clin. Med. 2021, 10, 1083. [CrossRef] [PubMed]

70. Octeau, D.; Faries, C.; Barnes, H.; Nakazawa, K.R.; Rao, A.J.; Ting, W.; Marin, M.L.; Vouyouka, A.G.; Faries, P.L.; Tadros, R.O. Neutrophil-to-Lymphocyte Ratio Associated With Adverse Events After Endovascular Aneurysm Repair (EVAR). Ann. Vasc. Surg. 2021, 75, 45-54. [CrossRef] [PubMed]

71. Lee, J.H.; Choi, J.H.; Kim, E.J. Volume of mural thrombus plays a role in the elevation of inflammatory markers after endovascular aortic repair. J. Cardiothorac. Surg. 2018, 13, 27. [CrossRef]

72. Lee, R.; Cassimee, I.; Huang, H.; Lapolla, P.; Ngetich, E.; Chandrashekar, A.; Charles, P.; Kessler, B.; Fischer, R.; Handa, A. Integrated Plasma and Tissue Proteomics Reveals Attractin Release by Intraluminal Thrombus of Abdominal Aortic Aneurysms and Improves Aneurysm Growth Prediction in Humans. Ann. Surg. 2020. [CrossRef] [PubMed]

73. Sartipy, F.; Lindstrom, D.; Gillgren, P.; Ternhag, A. The role of procalcitonin in postimplantation syndrome after EVAR: A pilot study. Ann. Vasc. Surg. 2014, 28, 866-873. [CrossRef]

74. Nessvi Otterhag, S.; Gottsater, A.; Acosta, S.; Palmqvist, B.; Lindblad, B. Inflammatory mediators after endovascular aortic aneurysm repair. Cytokine 2014, 70, 151-155. [CrossRef] [PubMed]

75. Noorani, A.; Sadat, U.; Rollins, K.E.; Chowdhury, M.M.; Tang, T.Y.; Harrison, S.C.; Usman, A.; Burling, K.; Nordon, A.; Boyle, J.R. Assessment of Renal Injury in Patients Undergoing Elective EVAR Using Urinary Neutrophil Gelatin-Associated Lipocalin, Interleukin 18, and Retinol-Binding Protein. Angiology 2017, 68, 547-552. [CrossRef] [PubMed]

76. Rampoldi, B.; Tessarolo, S.; Giubbilini, P.; Gaia, P.; Corino, S.D.; Mazza, S.; Rigolini, R.; Poli, M.D.; Vianello, E.; Romanelli, M.M.C.; et al. Neutrophil gelatinase-associated lipocalin and acute kidney injury in endovascular aneurysm repair or open aortic repair: A pilot study. Biochem. Med. 2018, 28, 010904. [CrossRef]

77. Obata, Y.; Kamijo-Ikemori, A.; Ichikawa, D.; Sugaya, T.; Kimura, K.; Shibagaki, Y.; Tateda, T. Clinical usefulness of urinary liver-type fatty-acid-binding protein as a perioperative marker of acute kidney injury in patients undergoing endovascular or open-abdominal aortic aneurysm repair. J. Anesth. 2016, 30, 89-99. [CrossRef] [PubMed] 
78. Obata, Y.; Kamijo-Ikemori, A.; Inoue, S. Clinical Utility of Urinary Biomarkers for Prediction of Acute Kidney Injury and Chronic Renal Dysfunction After Open Abdominal Aortic Aneurysm Repair. Int. J. Nephrol. Renov. Dis. 2021, 14, 371-384. [CrossRef] [PubMed]

79. Ousaka, D.; Fujii, Y.; Oozawa, S.; Nishibori, M.; Kuroko, Y.; Masuda, Z.; Sano, S. Decreased Serum Levels of High Mobility Group Box 1 (HMGB-1) after Graft Replacement or Stenting of Abdominal Aortic Aneurysm. Ann. Vasc. Surg. 2017, 41, 265-270. [CrossRef]

80. Pirgakis, K.M.; Makris, K.; Dalainas, I.; Lazaris, A.M.; Maltezos, C.K.; Liapis, C.D. Urinary cystatin C as an early biomarker of acute kidney injury after open and endovascular abdominal aortic aneurysm repair. Ann. Vasc. Surg. 2014, 28, 1649-1658. [CrossRef]

81. Wang, Y.; Ge, W.; Niu, L.; Yu, W.; Li, C.; Wang, H. Combined Detection of Plasma Tumor Necrosis Factor-alpha Converting Enzyme and Notch1 is Valuable in Screening Endoleak After Endovascular Abdominal Aortic Aneurysms Repair. Ann. Vasc. Surg. 2021, 76, 302-308. [CrossRef] [PubMed]

82. Whaley, Z.L.; Cassimjee, I.; Novak, Z.; Rowland, D.; Lapolla, P.; Chandrashekar, A.; Pearce, B.J.; Beck, A.W.; Handa, A.; Lee, R. The Spatial Morphology of Intraluminal Thrombus Influences Type II Endoleak after Endovascular Repair of Abdominal Aortic Aneurysms. Ann. Vasc. Surg. 2020, 66, 77-84. [CrossRef] [PubMed]

83. Yates, C.M.; Abdelhamid, M.; Adam, D.J.; Nash, G.B.; Bradbury, A.W.; Rainger, G.E. Endovascular aneurysm repair reverses the increased titer and the inflammatory activity of interleukin-1alpha in the serum of patients with abdominal aortic aneurysm. $J$. Vasc. Surg. 2011, 54, 497-503. [CrossRef]

84. Zettervall, S.L.; Dansey, K.; Swerdlow, N.J.; Soden, P.; Evenson, A.; Schermerhorn, M.L. Aspartate transaminase to platelet ratio index and Model for End-Stage Liver Disease scores are associated with morbidity and mortality after endovascular aneurysm repair among patients with liver dysfunction. J. Vasc. Surg. 2020, 72, 904-909. [CrossRef]

85. Zettervall, S.L.; Ultee, K.H.J.; Soden, P.A.; Deery, S.E.; Shean, K.E.; Pothof, A.B.; Wyers, M.; Schermerhorn, M.L. Predictors of renal dysfunction after endovascular and open repair of abdominal aortic aneurysms. J. Vasc. Surg. 2017, 65, 991-996. [CrossRef]

86. Lesiak, M.; Augusciak-Duma, A.; Stepien, K.L.; Fus-Kujawa, A.; Botor, M.; Sieron, A.L. Searching for new molecular markers for cells obtained from abdominal aortic aneurysm. J. Appl. Genet. 2021, 62, 487-497. [CrossRef]

87. Xie, X.; Wang, E.C.; Xu, D.; Shu, X.; Zhao, Y.F.; Guo, D.; Fu, W.; Wang, L. Bioinformatics Analysis Reveals the Potential Diagnostic Biomarkers for Abdominal Aortic Aneurysm. Front. Cardiovasc. Med. 2021, 8, 656263. [CrossRef]

88. Gan, S.; Pan, Y.; Mao, J. miR-30a-GNG2 and miR-15b-ACSS2 Interaction Pairs May Be Potentially Crucial for Development of Abdominal Aortic Aneurysm by Influencing Inflammation. DNA Cell Biol. 2019, 38, 1540-1556. [CrossRef]

89. Gan, S.; Shi, W.; Tang, J. miRNAs regulating the expressions of NTF3, GNG2 and ITGA7 are involved in the pathogenesis of abdominal aortic aneurysm in mice. Gen. Physiol. Biophys. 2021, 40, 1-16. [CrossRef]

90. Guo, S.; Li, Y.; Li, R.; Zhang, P.; Wang, Y.; Gopinath, S.C.B.; Gong, K.; Wan, P. High-performance detection of an abdominal aortic aneurysm biomarker by immunosensing. Biotechnol. Appl. Biochem. 2020, 67, 383-388. [CrossRef]

91. Cersit, S.; Ocal, L.; Keskin, M.; Gursoy, M.O.; Kalcik, M.; Bayam, E.; Karaduman, A.; Uysal, S.; Uslu, A.; Kup, A.; et al. Association of C-Reactive Protein-to-Albumin Ratio With the Presence and Progression of Abdominal Aortic Aneurysm. Angiology 2021, 72 , 153-158. [CrossRef]

92. Lu, H.Y.; Shih, C.M.; Sung, S.H.; Wu, A.T.H.; Cheng, T.M.; Lin, Y.C.; Shih, C.C. Galectin-3 as a Biomarker for Stratifying Abdominal Aortic Aneurysm Size in a Taiwanese Population. Front. Cardiovasc. Med. 2021, 8, 663152. [CrossRef]

93. Jablonska, A.; Zagrapan, B.; Neumayer, C.; Klinger, M.; Eilenberg, W.; Nanobachvili, J.; Paradowska, E.; Brostjan, C.; Huk, I. TLR2 2029C/T and TLR3 1377C/T and -7C/A Polymorphisms Are Associated with the Occurrence of Abdominal Aortic Aneurysm. J. Immunol. 2020, 204, 2900-2909. [CrossRef]

94. Jeong, S.J.; Cho, M.J.; Ko, N.Y.; Kim, S.; Jung, I.H.; Min, J.K.; Lee, S.H.; Park, J.G.; Oh, G.T. Deficiency of peroxiredoxin 2 exacerbates angiotensin II-induced abdominal aortic aneurysm. Exp. Mol. Med. 2020, 52, 1587-1601. [CrossRef]

95. Kim, E.N.; Yu, J.; Lim, J.S.; Jeong, H.; Kim, C.J.; Choi, J.S.; Kim, S.R.; Ahn, H.S.; Kim, K.; Oh, S.J. CRP immunodeposition and proteomic analysis in abdominal aortic aneurysm. PLOS ONE 2021, 16, e2245361. [CrossRef]

96. Li, L.; Shao, J.; Niu, W.; Che, H.; Song, F.; Liu, G.; Lu, S. Neutrophil Gelatinase-Associated Lipocalin as an Early Predictor of Contrast-Induced Nephropathy Following Endovascular Aortic Repair for Abdominal Aortic Aneurysm. Clin. Appl. Thromb./Hemost. Off. J. Int. Acad. Clin. Appl. Thromb./Hemost. 2021, 27, 10760296211025618. [CrossRef]

97. Li, T.; Wang, T.; Zhao, X. Profiles of immune infiltration in abdominal aortic aneurysm and their associated marker genes: A gene expression-based study. Braz. J. Med. Biol. Res. = Rev. Bras. De Pesqui. Med. E Biol. 2021, 54, e11372. [CrossRef]

98. Lieberg, J.; Wanhainen, A.; Ottas, A.; Vahi, M.; Zilmer, M.; Soomets, U.; Bjorck, M.; Kals, J. Metabolomic Profile of Abdominal Aortic Aneurysm. Metabolites 2021, 11, 555. [CrossRef]

99. Lindquist Liljeqvist, M.; Eriksson, L.; Villard, C.; Lengquist, M.; Kronqvist, M.; Hultgren, R.; Roy, J. Dipeptidyl peptidase-4 is increased in the abdominal aortic aneurysm vessel wall and is associated with aneurysm disease processes. PLOS ONE 2020, 15, e0227889. [CrossRef]

100. Maitiseyiti, A.; Ci, H.; Fang, Q.; Guan, S.; Shawuti, A.; Wang, H.; Ge, X. Identification of Novel Long Noncoding RNAs and Their Role in Abdominal Aortic Aneurysm. BioMed Res. Int. 2020, 2020, 3502518. [CrossRef]

101. Memon, A.A.; Zarrouk, M.; Agren-Witteschus, S.; Sundquist, J.; Gottsater, A.; Sundquist, K. Identification of novel diagnostic and prognostic biomarkers for abdominal aortic aneurysm. Eur. J. Prev. Cardiol. 2020, 27, 132-142. [CrossRef] 
102. Shi, F.; Ma, C.; Ji, C.; Li, M.; Liu, X.; Han, Y. Serum Lipid Oxidative Stress Products as Risk Factors Are the Candidate Predictive Biomarkers for Human Abdominal Aortic Aneurysms. Clin. Appl. Thromb. /Hemost. Off. J. Int. Acad. Clin. Appl. Thromb. /Hemost. 2020, 26, 1076029620932226. [CrossRef] [PubMed]

103. Tran, A.; Pope, A.; Dear, A.E. Point of care ankle pulse waveform: A biomarker for abdominal aortic aneurysm? Vascular 2021, 17085381211013976. [CrossRef]

104. Xie, T.; Yin, L.; Guo, D.; Zhang, Z.; Chen, Y.; Liu, B.; Wang, W.; Zheng, Y. The potential role of plasma fibroblast growth factor 21 as a diagnostic biomarker for abdominal aortic aneurysm presence and development. Life Sci. 2021, 274, 119346. [CrossRef]

105. Liu, P.; Sun, Z.; Zhang, Y.; Guo, W. Myeloid related protein 8/14 is a new candidate biomarker and therapeutic target for abdominal aortic aneurysm. Biomed. Pharmacother. = Biomed. Pharmacother. 2019, 118, 109229. [CrossRef]

106. Xu, W.; Chao, Y.; Liang, M.; Huang, K.; Wang, C. CTRP13 Mitigates Abdominal Aortic Aneurysm Formation via NAMPT1. Mol. Ther. J. Am. Soc. Gene Ther. 2021, 29, 324-337. [CrossRef]

107. Zhang, H.; Yang, D.; Chen, S.; Li, F.; Cui, L.; Liu, Z.; Shao, J.; Chen, Y.; Liu, B.; Zheng, Y. Identification of potential proteases for abdominal aortic aneurysm by weighted gene coexpression network analysis. Genome 2020, 63, 561-575. [CrossRef] 